Cultural Pessimism 
To Rosemary and Catherine 


\title{
Cultural Pessimism
}

\author{
Narratives of Decline \\ in the Postmodern World
}

Oliver Bennett

Edinburgh University Press 
(C) Oliver Bennett, 2001

Transferred to Digital Print 2009

Edinburgh University Press Ltd 22 George Square, Edinburgh

Typeset in New Baskerville by Hewer Text Ltd, Edinburgh, and Printed and bound in Great Britain by CPI Antony Rowe, Chippenham and Eastbourne

A CIP Record for this book is available from the British Library

ISBN 0748609369 (paperback)

The right of Oliver Bennett to be identified as author of this work has been asserted in accordance with the Copyright, Designs and Patents Act 1988. 